\title{
Review
}

\section{Prevalence of cagA and vacA among Helicobacter pylori-infected patients in Iran: a systematic review and meta-analysis}

\author{
Fatemeh Sayehmiri ${ }^{1}$, Faezeh Kiani ${ }^{1}$, Kourosh Sayehmiri ${ }^{2}$, Setareh Soroush ${ }^{3,4}$, Khairollah Asadollahi ${ }^{2}$, \\ Mohammad Yousef Alikhani ${ }^{5}$, Ali Delpisheh ${ }^{2}$, Mohammad Emaneini ${ }^{6}$, Lidija Bogdanović ${ }^{7}$, Ali Mohammad \\ Varzi $^{8}$, Raffaele Zarrilli ${ }^{7}$, Morovat Taherikalani ${ }^{8}$ \\ ${ }^{1}$ Student Research Committee, Ilam University of Medical Sciences, Ilam, Iran \\ 2 Prevention of Psychosocial Injuries Research Center, Ilam University of Medical Sciences, Ilam, Iran \\ ${ }^{3}$ Clinical Microbiology Research Center, Ilam University of Medical Sciences, Ilam, Iran \\ ${ }_{5}^{4}$ Department of Microbiology, School of Medicine, Ilam University of Medical Sciences, Ilam, Iran \\ ${ }^{5}$ Department of Microbiology, School of Medicine, Hamadan University of Medical Sciences, Hamadan, Iran \\ ${ }^{6}$ Department of Microbiology, School of Medicine, Tehran University of Medical Sciences, Tehran, Iran \\ ${ }^{7}$ Department of Public Health, University of Naples Federico II, Naples, Italy \\ ${ }^{8}$ Department of Microbiology, School of Medicine, Lorestan University of Medical Sciences, Khorramabad, Iran
}

\begin{abstract}
The varieties of infections caused by Helicobacter pylori may be due to differences in bacterial genotypes and virulence factors as well as environmental and host-related factors. This study aimed to investigate the prevalence of cagA and vacA genes among $H$. pylori-infected patients in Iran and analyze their relevance to the disease status between two clinical groups via a meta-analysis method.

Different databases including PubMed, ISI, Scopus, SID, Magiran, Science Direct, and Medlib were investigated, and 23 relevant articles from the period between 2001 and 2012 were finally analyzed. The relevant data obtained from these papers were analyzed by a randomeffects model. Data were analyzed using R software and STATA. The prevalence of cagA and vacA genes among $H$. pylori-infected patients was $70 \%(95 \% \mathrm{CI}, 64-75)$ and $41 \%(95 \% \mathrm{CI}, 24.3-57.7)$, respectively. The prevalence of duodenal ulcers, peptic ulcers, and gastritis among cagA+ individuals was 53\% (95\% CI, 20-86), 65\% (95\% CI, 34-97), and 71\% (95\% CI, 59-84), respectively. Odds ratio (OR) between cagA-positive compared with cagA-negative patients showed a 1.89 (95\% CI, 1.38-2.57) risk of ulcers. In conclusion, the frequency of $c a g A$ gene among $H$. pylori strains is elevated in Iran and it seems to be more frequently associated with gastritis. Therefore, any information about cagA and vacA prevalence among different $H$. pylori-infected clinical groups in the country can help public health authorities to plan preventive policies to reduce the prevalence of diseases associated with $H$. pylori infection.
\end{abstract}

Key words: $\operatorname{cagA}$; vacA; prevalence; H. pylori; meta-analysis; Iran.

J Infect Dev Ctries 2015; 9(7):686-696. doi:10.3855/jidc.5970

(Received 29 September 2014 - Accepted 01 April 2015)

Copyright ( 92015 Sayehmiri et al. This is an open-access article distributed under the Creative Commons Attribution License, which permits unrestricted use, distribution, and reproduction in any medium, provided the original work is properly cited.

\section{Introduction}

Helicobacter pylori infection is a prevalent disease that affects more than half of the world's population. It is the most common infectious bacteria of the stomach and can persist in many conditions in which other bacteria are not able to live [1]. H. pylori is a Gramnegative and microaerophilic bacillus that is recognized as a special pathogen of the human stomach. It causes a chronic inflammation of gastric mucosa by infiltration of neutrophils, lymphocytes, and plasma cells into the gastric mucosa. This bacillus is the etiological cause of peptic ulcers, adenocarcinoma of stomach, and MALT lymphoma, and has been associated with ischemic heart disease, adenotonsillar disease, and other types of malignancies [1-4]. H. pylori is able to colonize the human gastric mucosa and create a persistent infection associated with acute or chronic inflammation [5]. Mucosal gastritis occurs in all infected patients; however, only a small number of these patients show clinical symptoms and relevant complications such as peptic ulcers, gastritis, or gastric cancer [6]. Contamination with $H$. pylori in developing countries is high, and a prevalence of more than $80 \%$ has been reported. Also, the severity of $H$. pylori-dependent gastro-duodenal diseases is influenced by bacterial, environmental, and genetic factors [2]. The relevant mechanisms involved in different aspects of the diseases have not been fully 
elucidated yet; however, a combination of different virulence factors in different $H$. pylori strains may play a role [6]. Nevertheless, the cytotoxin-associated gene $\mathrm{A}(\mathrm{cag} A)$ and the vacuolating cytotoxin $(\mathrm{vacA})$ are the two main $H$. pylori virulence factors identified among the bacterial markers associated with pathogenesis of different strains [6].

Mounting evidence indicates a positive relationship between the presence of $H$. pylori cagA+ strains and the development of peptic/duodenal ulcers and gastric cancer in infected patients [5].

$H$. pylori cagAt strains carry a $40 \mathrm{kbp}$ pathogenicity island, which contains the $\operatorname{cag} A$ gene that encodes cagA and genes that encode a type IV secretion system, through which $\operatorname{cag} A$ and other bacterial virulence factors are injected into host cells [7]. The cagA gene is present in about $50 \%-70 \%$ of strains, and in some Asian countries, its prevalence is about 90\% [2]. According to variation seen at its tyrosine phosphorylation-SHP-2 binding site, cagA has been sub-classified in two main types, Western cagA and East Asian $\operatorname{cag} A$, the latter being more biologically active and accounting for the high incidence of gastric carcinoma in East Asian countries [7]. After injection into host epithelial cells, $\operatorname{cagA}$ is tyrosine phosphorylated and activates the Ras-MAPK (mitogen-activated protein kinase) kinase pathway. This induces cell growth and motility of gastric epithelial cells along with alteration of epithelial cell differentiation [7].

VacA is an $88 \mathrm{kDa}$ protein toxin that was identified by its ability to induce the formation of cytoplasmic vacuoles in cultured cells [8]. It has been suggested that VacA acts as a multifunctional toxin. Indeed, VacA has been reported to induce cell damage of gastric epithelial cells and to exert an immunosuppressive action through inhibition of antigen presentation and T-lymphocyte activation. Although the gene encoding $\operatorname{VacA}$ (vacA) is present in all $H$. pylori strains, allele variations exist in the VacA secretion signal sequence (allele types s1 or S1) and the mid-region (alleles types $\mathrm{m} 1$ or $\mathrm{m} 2$ ) [9].

The isolates carrying $v a c A$ and $\operatorname{cag} A$ create more severe inflammation. There are many studies, with different findings, about the existence or absence of $\operatorname{cag} A$ and its treatment [3]. According to different studies, isolates possessing $\operatorname{cag} A$ increase the risk of special clinical aspects, but their incidences are not predictable [6].

This study aimed to investigate the prevalence of cagA and vacA among $H$. pylori-infected patients developing peptic ulcer disease (PUD), non-ulcer
Flowchart 1. The flowchart of selected articles for final analysis

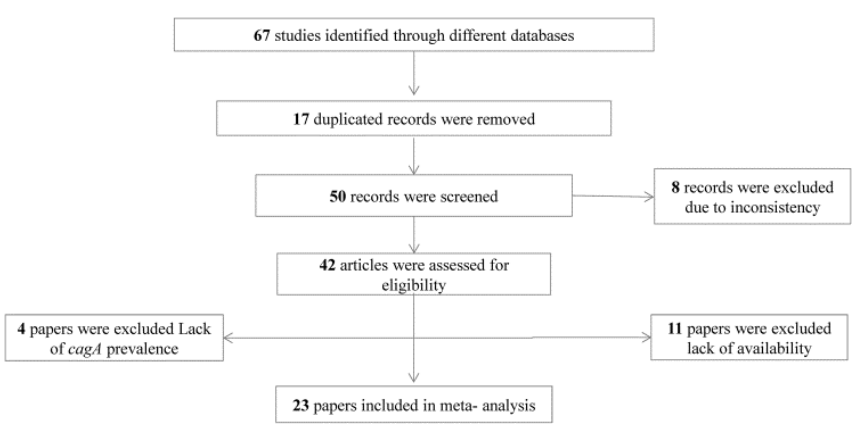

disease (NUD), gastritis, and gastric cancer in Iran using a meta-analysis method.

\section{Methodology}

\section{Search method}

All associated published papers in national and international journals of PubMed, Scopus, ISI, Magiran, IranMedex, Science Direct, Medlib, and SID databases were evaluated. Searching was done in a systematic way using keywords cagA, vacA, prevalence, $H$. pylori, Iran, and meta-analysis (both in English and Persian).

\section{Paper selection}

First, a list of 67 papers and abstracts yielded by the keyword search, was prepared and evaluated for relevance. Of these studies, 17 were excluded because they were repetitive, 8 were not consistent with the study criteria, the full texts of 11 papers were not accessible and their abstracts did not contain enough information, and 8 papers did not reveal the prevalence of $\operatorname{cagA}$; all of these papers were withdrawn (Flowchart 1). Finally, 23 relevant papers [2-4,6,10-28] were identified. Their data were entered into the data collection forms, and then these data were entered into Microsoft Excel and were analyzed using $\mathrm{R}$ software (version 11.2) and STATA (version 10).

\section{Statistical analysis}

The main objective of the study was to evaluate the prevalence of $\operatorname{cagA}$ and $v a c A$; therefore, its variance was estimated by binominal distributions. To pool prevalence reported by different studies, weighting averaging was used. Each study was given a weight equal to its inverse variance. For evaluation of heterogeneity, Q test and $\mathrm{I}^{2}$ index, at the type I error of smaller than 0.10 , were applied. Wherever the results of studies were heterogeneous, the analysis was performed using a random-effects model. The random- 
effects model was used because there was significant heterogeneity among the results of the studies $\left(\mathrm{I}^{2}=\right.$ $92 \%, \mathrm{p}=0.000$ ). To pool the results of the studies, two main approaches were used: the fix effects model and the random-effects model. When heterogeneity among the results of the studies was not significant, the fix effects model was used to pool analysis and verses. In a two-by-two cross-sectional table, odds ratio was (OR) computed using the formula:

$$
O R=\frac{a d}{b c}
$$

The $95 \%$ confidence interval (CI) was computed using the formula:

$$
\operatorname{Ln}(O R) \pm Z_{1-\alpha_{2}} S E(\operatorname{Ln}(O R))
$$

That:

$$
S E(\operatorname{Ln}(O R))=\sqrt{\frac{1}{a}+\frac{1}{b}+\frac{1}{c}+\frac{1}{d}}
$$

Funnel plot is a graphical detection of publication bias. The funnel plot is a bivariate scatter plot $(x, y)$ of the study sample size against the study estimate of treatment difference or effect size. There is a formal test for publication bias based on linear regression analysis. It includes both intercept and slope parameters and is given by $y_{i}=\alpha+\beta x_{i}+\varepsilon_{i}$,

for $i=1, \ldots, r$, where $r$ is the number of studies, $y_{i}$ is the standardized estimate, $x_{i}$ is the precision of

\begin{tabular}{|c|c|c|c|c|c|c|c|c|c|c|c|c|c|}
\hline Authors & $\begin{array}{c}\text { Publicatio } \\
\text { n } \\
\text { year }\end{array}$ & City & $\begin{array}{c}\text { Sample } \\
\text { size }\end{array}$ & $\begin{array}{c}\mathbf{N} \\
(\mathbf{P U D})\end{array}$ & $\begin{array}{c}\mathbf{N} \\
(\mathbf{N U D})\end{array}$ & Age & $\begin{array}{c}\text { VacA } \\
\text { prevalenc } \\
\text { e } \\
\text { (total) } \\
\%\end{array}$ & $\begin{array}{c}\operatorname{Cag} A \\
\text { prevalence } \\
\text { (total) } \\
\%\end{array}$ & $\begin{array}{c}\operatorname{CagA} \\
\text { prevalence } \\
\text { (PUD) }\end{array}$ & $\begin{array}{c}\operatorname{Cag} A \\
\text { prevalence } \\
\text { (NUD) }\end{array}$ & $\begin{array}{c}\text { Duodenal } \\
\text { ulcer } \\
\operatorname{cag}^{+}\end{array}$ & $\begin{array}{c}\text { Gastric } \\
\text { ulcer } \\
\operatorname{cag}^{+}\end{array}$ & $\begin{array}{c}\text { Gastritis } \\
\operatorname{cag}^{+}\end{array}$ \\
\hline $\begin{array}{c}\text { Shokohizadeh } \\
{[10]}\end{array}$ & 2006 & Tehran & 54 & & & 42 & & $35(22-48)$ & & & 26 & & \\
\hline Farshad[6] & 2009 & Shiraz & 65 & 30 & 35 & $\begin{array}{l}14 \pm \\
41.3\end{array}$ & $57(45-69)$ & $48(36-60)$ & 60 & 37.2 & & & \\
\hline $\begin{array}{c}\text { Latifi-Navid } \\
{[11]}\end{array}$ & 2010 & Tehran & 144 & & & & & $72(65-79)$ & & & & & \\
\hline $\begin{array}{c}\text { Shokri } \\
\text { Shirvani [12] }\end{array}$ & 2008 & Babol & 30 & & & & & $80(66-94)$ & & & 73 & 67 & 91.7 \\
\hline Khaleghi [3] & 2009 & Tehran & 56 & 22 & 34 & $\begin{array}{c}12.77 \\
\pm \\
42.92\end{array}$ & & $64(52-77)$ & 41.66 & 58.33 & & & \\
\hline Khodaei [4] & 2013 & Tehran & 140 & 105 & 35 & $\begin{array}{l}7.3 \pm \\
41.1\end{array}$ & $38(29-46)$ & $70(62-78)$ & 69.23 & 68.6 & 81 & 70 & 56.3 \\
\hline $\begin{array}{c}\text { Mollabashi } \\
\text { [13] }\end{array}$ & 2012 & Isfahan & 16 & & & & & $19(-0.0-38)$ & & & & & \\
\hline Souod [14] & 2013 & Shahrekord & 164 & & & $\begin{array}{c}17 \pm \\
47\end{array}$ & $17(11-22)$ & $92(88-96)$ & & & 13 & 9 & 89.63 \\
\hline $\begin{array}{c}\text { Bazargani } \\
{[15]}\end{array}$ & 2007 & Shiraz & 120 & 51 & 69 & $18-68$ & & 69 (61-77) & 82.3 & 59.4 & & & \\
\hline Aqajani [16] & 2002 & Shahrod & 135 & & & & & $75(68-82)$ & & & & & \\
\hline Shirazi [17] & 2008 & Tehran & 92 & 58 & 34 & & & 85 (78-92) & 69.55 & 64.7 & 100 & 90 & \\
\hline Goudarzi [2] & 2012 & Tehran & 84 & & & 56.6 & & 64 (54-74) & & & & 77 & 50 \\
\hline $\begin{array}{l}\text { Ghasemian } \\
\text { Safaei [18] }\end{array}$ & 2008 & Isfahan & 100 & & & & & 68 (59-77) & & & 73 & & 65 \\
\hline $\begin{array}{c}\text { Douraghi } \\
\text { [19] }\end{array}$ & 2008 & Tehran & 120 & 17 & 81 & & & $84(78-91)$ & 94.1 & 74.1 & & & \\
\hline Molaei [20] & 2009 & Tehran & 86 & & & & $91(85-97)$ & $77(68-86)$ & & & & & \\
\hline $\begin{array}{l}\text { Ghasemi } \\
\text { kebria [21] }\end{array}$ & 2011 & Golestan & 683 & & & & & $58(54-61)$ & & & & & \\
\hline $\begin{array}{c}\text { Ghotaslou } \\
{[23]}\end{array}$ & 2013 & Tabriz & 115 & 62 & 53 & & 37 (29-46) & $69(60-78)$ & 40.9 & 27.8 & & & \\
\hline Nahaei [36] & 2008 & Tabriz & 150 & 33 & 117 & 37.5 & $30(23-37)$ & $83(77-89)$ & 93.9 & 80.3 & & & \\
\hline Bojary [24] & 2004 & Tehran & 92 & & & 47 & & $70(61-79)$ & & & & & \\
\hline Nawfal [22] & 2008 & Tehran & 59 & 17 & 42 & $\begin{array}{c}14 \pm \\
40\end{array}$ & & $76(65-87)$ & 76 & 76 & & & \\
\hline $\begin{array}{c}\text { Kamali- } \\
\text { Sarvestani } \\
{[26]}\end{array}$ & 2006 & Shiraz & 286 & & & $\begin{array}{c}16.6 \pm \\
45.3\end{array}$ & $33(28-39)$ & $77(72-82)$ & & & & 81 & 74.4 \\
\hline Jafari [27] & 2008 & Tehran & 96 & 19 & 74 & 44 & $29(20-38)$ & $76(67-85)$ & 79 & 74.3 & & & \\
\hline Dabiri [28] & 2009 & Tehran & 124 & 22 & 91 & $\begin{array}{c}17 \pm \\
46 \\
\end{array}$ & $38(27-49)$ & $68(60-76)$ & 55 & 73 & & & \\
\hline
\end{tabular}
studies, and $\varepsilon_{i}$ is the error terms.

Table 1. Characteristics of different investigated studies

PUD: peptic ulcer disease; NUD: non-ulcer disease 


\section{Results}

Twenty-three relevant papers from between 2001 and 2012 in Iran were included in the meta-analysis (Table 1). The total number of evaluated patients infected by $H$. pylori was 3,011. Due to high heterogeneity of the studies' findings, a random-effects model was applied for all further steps. The prevalence of cagA among $H$. pylori-infected patients was $70 \%$ (95\% CI, 64-75) (Figure 1) and 71\% (95\% CI, 65-77) in 12 studies from Tehran province. The vacA prevalence in total was 38.2 (95\% CI, 22.3-54); in NUD, it was $29.7 \%$ (95\% CI, 21.8-37.7) and in PUD, $38.2 \%$ (95\% CI, 22.3-54) (Figure 2). The cagA prevalence for Shiraz, Babol, Isfahan, Shahrkord, Shahroud, Golestan, and Tabriz was 65\% (95\% CI, 51-80), 80\% (95\% CI, 66-94), 44\% (95\% CI, 4-92), 92\% (95\% CI, 88-96), 75\% (95\% CI, 67-82), 58\% (95\% CI, 54-61), and 76\% (95\% CI, 62-91), respectively. In 11 studies, the prevalence of cagA among patients with PUD and those with NUD was analyzed (Figure 3). Patients with positive $\operatorname{cag} A$ compared to those with negative $\operatorname{cag} A$ showed risk of peptic ulcer of 1.89 (95\% CI, 1.38-2.57) (Table 2). A statistically significant relationship between cagA positivity and $H$. pylori infection was found when data of all eleven studies were combined. The prevalence of duodenal ulcers (reported by six studies), peptic ulcers (reported by six studies), and gastritis (reported by six studies) among individuals infected with $H$. pylori cagA+ strains was 53\% (95\% CI, 20-86), 65\% (95\% CI, 34-97), and $71 \%$ (95\% CI, 59-84), respectively. According to the publication bias figure, the effect of bias in these studies was not significant. In fact, most studies were located inside the funnel plot, thus demonstrating that the results of most relevant studies performed in Iran were included in the

Table 2. The overall results of different selected studies and prevalence of gastric cancer and gastritis in the Helicobacter pylori-infected population

\begin{tabular}{|c|c|c|}
\hline & $\begin{array}{c}\text { Number of } \\
\text { studies }\end{array}$ & $\begin{array}{c}\text { Prevalence (random effects model) } \\
(95 \% \mathrm{CI})\end{array}$ \\
\hline Mean age of participants & 12 & 44.24 \\
\hline Prevalence of $\operatorname{cag} A$ & 23 & $64-75(70)$ \\
\hline Prevalence of $c a g A$ in Shiraz & 3 & $51-80(65)$ \\
\hline Prevalence of $\operatorname{cagA}$ in Babol & 1 & $66-94(80)$ \\
\hline Prevalence of $c a g A$ in Isfahan & 2 & $4-92(44)$ \\
\hline Prevalence of $c a g A$ in Shahrod & 1 & $67-82(75)$ \\
\hline Prevalence of $c a g A$ in Golestan & 1 & $54-61(58)$ \\
\hline Prevalence of cagA in Tabriz & 2 & $62-91(76)$ \\
\hline Prevalence of duodenal ulcer $\operatorname{cag} A+$ & 6 & $20-86(53)$ \\
\hline Prevalence of gastric ulcer $c a g A+$ & 6 & $34-97(65)$ \\
\hline Prevalence of gastritis $\mathrm{cagA}^{+}$ & 6 & $59-84(71)$ \\
\hline Prevalence of $v a c A$ (NUD) & OR & $\begin{array}{c}95 \% \mathrm{CI} \\
\text { (random effects model) }\end{array}$ \\
\hline Prevalence of gastric cancer (total) & 8.9 & $2.4-15.4$ \\
\hline Prevalence of gastritis (total) & 58.5 & 29.3-87.6 \\
\hline Prevalence of gastric cancer $\operatorname{cag} A+$ & 0.10 & $0.02-0.18$ \\
\hline Prevalence of gastritis $\mathrm{cagA+}$ & 0.31 & $-0.03-0.66$ \\
\hline Prevalence of gastric cancer $c a g A$ - & 0.21 & $-0.10-0.53$ \\
\hline Prevalence of gastritis $\mathrm{cagA-}$ & 0.65 & $0.45-0.86$ \\
\hline Prevalence of gastric cancer $v a c A$ & 0.08 & $-0.01-0.18$ \\
\hline Prevalence of gastritis $v a c A$ & 0.53 & $0.23-0.84$ \\
\hline Prevalence of $\operatorname{cagA+}$ & 0.70 & $0.61-0.79$ \\
\hline
\end{tabular}


Figure 1. Prevalence of cagA and its $95 \%$ confidence interval using a random-effects model .Midpoint of each line segment represents the estimated prevalence in the study. Rhombic mark shows the prevalence in Iran, extracted from all studies.

\begin{tabular}{l} 
Study \\
ID \\
\hline Aghajani (2002) \\
Bojary (2004) \\
Bazargani (2005) \\
Shokohizadeh (2006) \\
Shirazi (2006) \\
Kamali (2006) \\
Latifinavid (2007) \\
Shokrishirvani (2007) \\
Ghasemian (2008) \\
Nahaei (2008) \\
Nawfal (2008) \\
Jafari (2008) \\
Farshad (2009) \\
Khaleghi (2009) \\
Douraghi (2009)
\end{tabular}

Figure 3. The results of meta-analysis of $H$. pylori infections among PUD and NUD individuals.

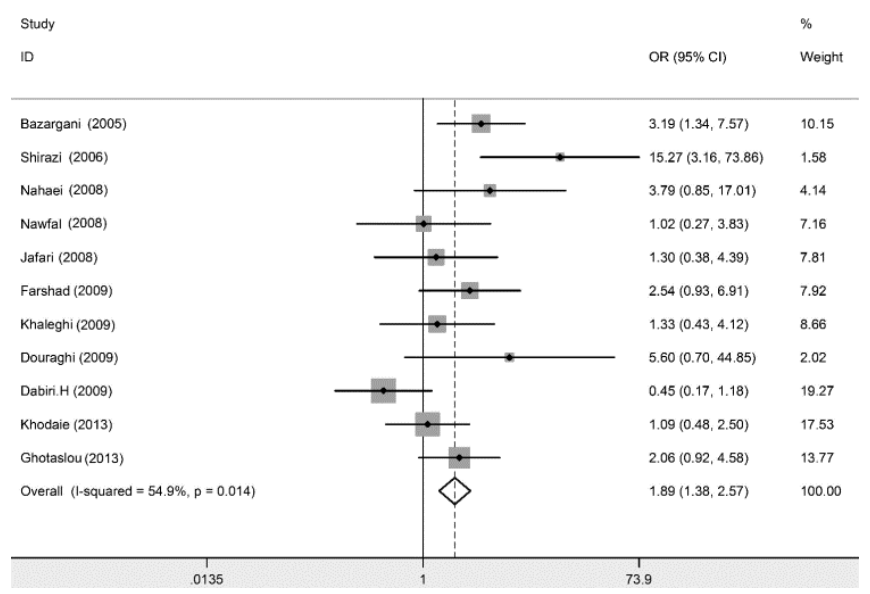

Odds ratio (OR) and 95\% confidence intervals for each study and in summary with weighting in a fixed-effects model are shown. OR $>1.0$ indicates the higher probability of eradication failure of $\operatorname{cag} A$-negative H. pylori-infected patients compared with cagA-positive $H$. pyloriinfected patients.
Figure 2. Prevalence of $v a c A$ and its $95 \%$ confidence interval using a random-effects model.

Midpoint of each line segment represents the estimated prevalence in the study. Rhombic mark shows the prevalence in Iran, extracted from all studies.

\begin{tabular}{|c|c|c|c|}
\hline \multicolumn{3}{|l|}{ Study } & $\%$ \\
\hline ID & & ES $(95 \% \mathrm{Cl})$ & Weight \\
\hline Kamali (2006) & & $0.33(0.28,0.39)$ & 11.30 \\
\hline Nahaei (2008) & $\rightarrow$ & $0.30(0.23,0.37)$ & 11.19 \\
\hline Jafari (2008) & - & $0.29(0.20,0.38)$ & 11.06 \\
\hline Farshad (2009) & $\rightarrow$ & $0.57(0.45,0.69)$ & 10.79 \\
\hline Molaei (2009) & & $\rightarrow 0.91(0.85,0.97)$ & 11.26 \\
\hline Dabiri (2009) & & $0.38(0.27,0.49)$ & 10.89 \\
\hline Khodaie (2013) & & $0.38(0.29,0.46)$ & 11.14 \\
\hline Souod (2013) & $\rightarrow$ & $0.17(0.11,0.22)$ & 11.29 \\
\hline Ghotaslou (2013) & & $0.37(0.29,0.46)$ & 11.08 \\
\hline Overall (I-squared $=97.7 \%, p=0.000$ ) & & $0.41(0.24,0.58)$ & 100.00 \\
\hline NOTE: Weights are from random effects analysis & & & \\
\hline -.968 & & .968 & \\
\hline
\end{tabular}

Figure 4. Begg's funnel plot for publication bias in the risk difference (RD) analysis.

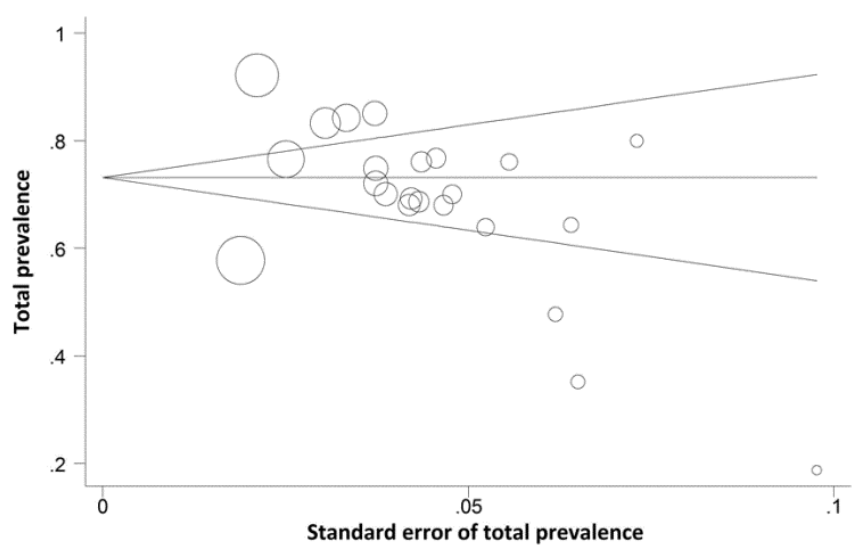

Each circle represents the RDs for eradication success between cagApositive and $\operatorname{cag} A$-negative according to the standard error of each RDs. The diameter of each circle represents the weight in the meta-analysis. 
Table 3. Source of heterogeneity by multivariate meta-regression analysis

\begin{tabular}{cccc}
\hline Factors & Coefficient & Standard error & P value \\
\hline Published year & -0.0065 & 0.0112 & $\mathbf{0 . 5 7}$ \\
Sample Size & 0.000033 & 0.000024 & $\mathbf{0 . 8 9}$ \\
\hline
\end{tabular}

analysis (Figure 4). Interpretation of meta-regression showed that there was no significant relationship between prevalence of $\operatorname{cagA}$ and the year of study ( $\mathrm{p}=$ 0.57) (Table 3).

\section{Discussion}

The current meta-analysis study evaluated the prevalence of $\operatorname{cagA}$ and $v a c A$ in a total sample size of 3,011 patients infected with $H$. pylori in Iran between 2001 and 2012. In the current study, the prevalence of cagA among patients infected with $H$. pylori was $70 \%$, which was in accordance with reports from Iraq (71\%) and Turkey (78\%) [25,29]. It was also consistent with reports from Europe and North America [30,34]. However, the prevalence obtained from the present study was lower than that reported from Southeast Asia (93\% positive for cagA) by a similar metaanalysis study [35]. Podzorski et al. from the United States reported that only $66 \%$ of $H$. pylori isolates were positive for cagA [36]. Zhou et al. from China reported a prevalence of $93.9 \%$ for $\operatorname{cag} A$ among $H$. pylori isolates [37]; however, this figure for the Netherlands, Germany, Estonia, and Sri Lanka was $46 \%, 87.2 \%, 87 \%$, and $45 \%$, respectively [38]. A study from Brazil reported a prevalence of $81.7 \%$ for the cagA gene among $H$. pylori isolates [39]. There is a variety in the distribution of $\operatorname{cagA}$ among $H$. pylori isolates in different parts of the world [40]. According to evidence, more than $90 \%$ of isolates form Eastern populations included $\operatorname{cagA}$ [41]. The prevalence found in the current study was different from that reported from South and East Asian countries, in which a prevalence of more than $90 \%$ was reported $[42,43]$. For example, a prevalence of $97 \%, 95 \%, 94 \%$, and 90\% was reported for cagA among $H$. pylori isolates from Korea, Japan, Malaysia, and China, respectively [44-45,23-24]. Our findings were more similar to those reported from European and American countries that ranged between $60 \%$ and $70 \%$ [46]. In partial support of this, a recent study showed that $H$. pylori isolates from infected patients in Iran displayed a large variability in the polymorphisms of cagA and vacA genes [47]. This may be due to the location of this country in the Middle East; it may have a combination of Western and Eastern isolates of H. pylori [47].
CagA pathogenicity island of is one of the most important markers of $H$. pylori pathogenesis, so isolates without this island have lower abilities for pathogenesis. The cagA gene is the biggest segment of this island; therefore, the presence of the cagA gene can be an existence marker of this island [19]. The prevalence of isolates with $\operatorname{cag} A$ among different geographical areas is also different, which may be related to the difference between studied populations and/or genetic varieties of investigated isolates. This finding of our study was in accordance with reports from East Asian countries [48].

A previous meta-analysis study demonstrated that the prevalence of $H$. pylori infection in Iran was $50.7 \%$ (95\% CI, 44.4-56.9) [49]. The frequencies of peptic ulcers and gastric malignancy are highly affected by ethnical and geographical variables; therefore, these findings combined with the lower efforts for $H$. pylori eradication in Iran as well as a considerable of recurrent infections may indicate a high developmental process of Iranian isolates [11].

Mounting evidence demonstrates that the genetic variability of $H$. pylori strains is dependent on the geographical and ethnic status of human hosts [11]. A study by Latifi et al. analyzed the sequences of housekeeping genes and revealed that genetic characteristics of $H$. pylori in Iran were affected by genetic interchanges with neighboring countries, and that there were considerable ethnical and geographical differences inside Iran [50].

This finding was in accordance with our results about differences in the local prevalence of cagA obtained from Tehran (71\%), Shiraz (65\%), Babol (80\%), Isfahan (44\%), Shahrkord (92\%), Shahroud (75\%), Golestan (58\%), and Tabriz (76\%). Internal studies on the $\operatorname{cag} A$ gene in Iran showed contradictory results; in some studies, the difference between reported prevalence of cagA was more than 50\%. One of the reasons for these contradictory results was the different sensitivities of the methods used for identification of cagA and $H$. pylori infections in different studies [51-53]. H. pylori has been confirmed as an important pathogen in the human gastric tract, and different isolates of these bacteria cause a variety of gastrointestinal disorders resulting in complications 
such as injury of gastric mucosa, transformation of tissue stratum, chronic inflammation, chronic gastritis, PUD, and gastric malignancy. However, not all involved patients suffer from these complications, and more than $50 \%$ of involved patients do not show any symptoms. Genetic pathogenesis of different isolates and environmental characteristics are essential factors related to this discrepancy $[6,24]$. CagA as a product of the $\operatorname{cagA}$ gene has been introduced as the main pathogen factor in $H$. pylori and acts as a provoker for different disorders related to this microorganism. The effects of CagA in the induction of local inflammatory response, progress of PUD, and gastric malignancy have been recognized [52,64]. Our study showed a higher frequency of patients with $\operatorname{cag} A$ among patients with PUD compared to those with NUD. It has been reported that patients with NUD are more resistant to H. pylori-eradication therapy than individuals with PUD. Additionally, there is some influence of $\operatorname{cagA}$ status on eradication in NUD patients, a possibility which warrants further investigation given the link between cagA status and improvement of symptoms in NUD patients in whom eradication is successful [55]; however, this difference was found not to be significant. Almost all previous studies have shown a higher frequency of positive cagA among patients with PUD compared to those with NUD; however, these differences were statistically significant in only some of these studies [56-58] (inconsistent with our results) and not significant in others [59-61] (consistent with our results). In further support of a correlation between $\operatorname{cag} A$ positivity and PUD, it has been demonstrated that cytotoxic $\operatorname{cag} A$-positive strains cause more profound inhibition of mucin synthesis, thus suggesting that the increased inhibitory effect of $\operatorname{cagA}$ positive, cytotoxin-producing strains on mucin synthesis increases the risk of developing peptic ulceration [48].

In the populations of Western countries, particular genotypes of the vacuolating cytotoxin gene vacA (vacA s, signal region variants; vacA $\mathrm{m}$, middle region variants) of $H$. pylori have been associated with high risk of developing peptic ulcers and gastric cancer [62].

In the current study, the prevalence of duodenal ulcers, peptic ulcers, and gastritis among patients with positive cagA was $53 \%, 65 \%$, and $71 \%$, respectively. In previous studies, the presence of cagA was associated with severe gastric disorders such as severe gastritis, duodenal ulcers, peptic ulcers, and gastric malignancy [63-65]. Our findings, similar to these studies, showed high frequency of these disorders among patients with $\operatorname{cagA}$. Aydin et al. reported a prevalence of $72.2 \%$ cagA among isolates detected from patients with peptic ulcers in Turkey [66]. Figueredo and colleagues reported a prevalence of $56 \%, 90 \%, 88 \%$, and $88 \%$ of cagA among isolates detected from patients with gastritis, duodenal ulcers, peptic ulcers, and gastric cancer, respectively [67]. Arents et al. showed a higher prevalence in the Netherlands of $\operatorname{cagA}$ among patients with peptic ulcers compared with patients with other diseases [68]. Also, other studies from Iraq [25], Turkey [29], and Saudi Arabia [69] reported a relationship between the $\operatorname{cagA}$ gene and gastric cancer or peptic ulcers. A study from Italy demonstrated that the prevalence of the $\operatorname{cagA}$ gene among patients with duodenal ulcers and peptic ulcers was $86.1 \%$ and $96.4 \%$, respectively [70]. Gzyl et al. reported a positive relationship between cagA gene and incidence of acute gastritis among child and adult patients [71]. According to different reports, either numbers or features of different motifs are changed by alteration of geographical locations, and their clinical outcomes are also affected by this variation. Western Asian isolates are therefore different from Eastern Asian isolates [11], and Eastern Asian isolates are more associated with gastric cancer than are Western isolates [72]. For example, studies by Zhou et al. [37] and Chen et al. [57] reported the prevalence of $\operatorname{cagA}$ among isolates associated with peptic ulcers and gastric cancers to be $100 \%$ and $94 \%$, respectively. Some studies from Western countries reported a relationship between severity of diseases and the prevalence of $\operatorname{cagA}$ among associated isolates, but studies from East Asia reported no significant relationship between these variables [73-74] and concluded that clinical results could not be predicted by the prevalence of $\operatorname{cagA}$ among Asian countries [7576]. Moreover, meta-analyses identified a significant relationship between $v a c A$ m-region genotype and $\operatorname{cag} A$ status and the development of diseases in Southeast Asia. Importantly, most of the H. pylori strains isolated from countries with high incidences of gastric cancer and anti-cagA antibody can be used as a biomarker for gastric cancer even in East Asian countries [55,77-78].

Our study showed higher frequency of the $\operatorname{cagA}$ gene among patients with gastritis, but this was not statistically significant. Despite the difference in the frequency of $\operatorname{cagA}$ among different types of diseases, a relationship between the presence or absence of cagA and the severity of disease can be assumed. The current study showed that more than $70 \%$ of Iranian isolates were positive for $\operatorname{cag} A$. High frequency of 
cagA among isolates does not necessarily lead to severe diseases such as severe gastritis, peptic ulcers, or gastric cancer; however, this finding may be due to excess numbers of alleles among cagA genes in Iranian isolates.

Discrepancies between different reports about the severity of immune responses and the incidence of clinical outcomes for isolates with positive cagA may be associated with environmental and genetic factors of either host or bacteria. Examples for these are gene polymorphisms of inflammatory cytokines, difference in individual immune systems, and genetic differences in bacterial virulence genes such as vacA, ice A, and several genes included in the cag pathogenicity island [79-80]

Polymorphisms in interleukin (IL)-1B, IL-1RN, IL-8, IL-10, and tumor necrosis factor alpha (TNF- $\alpha$ ), which are involved in $H$. pylori infection, increase risk of gastric cancer [81-82].

Despite the relationship of these well-known genes with clinical outcomes, it seems this subject is still a controversial problem; for clarity of this ambiguity, execution of studies with bigger sample sizes and in different geographical places of Iran is suggested [10]. Some limitations of this study were the lack of comparison between the prevalence of $\operatorname{cagA}$ gene and age/gender groups of patients; the lack of comparison between peptic ulcers and age/gender groups; and the unavailability of some studies associated with prevalence of $\operatorname{cagA}$.

\section{Conclusions}

Considering the high prevalence of $H$. pylori infection and its serious outcomes, early diagnosis of this bacteria and characterization of $\operatorname{cag} A$ and $v a c A$ status of $H$. pylori strains using polymerase chain reaction (PCR) is important for the prevention and timely treatment of associated infection. In this study, we revealed a high prevalence of the $\operatorname{cag} A$ gene in Iran and a more significant correlation between $\operatorname{cag} A$ gene positivity in gastritis compared with other diseases. Due to dispersal uniformity of $\operatorname{cag} A$ genes among all disease groups, the presence of the cagA gene cannot be considered solely as a determinant marker of clinical outcome for H. pylori infection. Therefore, the clinical features of diseases associated with $H$. pylori infection are mostly related to bacterial, environmental, and host-related factors. Due to the complexity features of diseases associated with $H$. pylori infection, identification of new acutenessrelated factors and expansion of their monitoring in the different geographical areas is necessary.

\section{Acknowledgements}

The authors extend their gratitude to the Student Research Committee, Ilam University of Medical Sciences for its support.

\section{References}

1. Esmaeili D, Mobarez MA, Salmanian HA, Zavaran A, Mahdavi M (2010) Synergistic effect of $\mathrm{rCagA}$ and LPS of $H$. pylori $\mathrm{O} 2$ serotype in induction of proper immune response against $H$. pylori. Arak Med Univ J 8: 1-5.

2. Goudarzi H, Rezaee H, Rafizadeh M, Taghavi A, Mirsamadi E (2012) The frequency of cagA gene of $H$. pylori isolated from biopsy specimen in Tehran during 2008-2010. Arak Med Univ J 15: 42-48.

3. Khaleghi S, Talebi TM, Parhizcar B, Entezari A (2009) Comparison of anti-H. pylori therapeutic responses in two groups of patients with and without cagA Ab. SJKU 14: 5964.

4. Khodaii Z, Tabatabaei Panah A, Ghaderian S, Akbarzadeh Najar R (2013) Investigation of vacA status and cagA in patients with peptic ulcer disease. Bimonth Offic Public Med Daneshvar 20: 1-8.

5. Bonyadi MR, Fattahi A, Pozesh Sh, Abbasalizadeh S, Khoshbaten MR (2011) Helicobacter pylori CagA-positive strains was determined by ELISA technique and assessment of Helicobacter pylori in dyspeptic patients seropositive adults East Azerbaijan. Med Lab J 54: 37-39.

6. Farshad S, Japoni A, Kalani M (2009) Genes associated UreAB, VacA, CagA strains of $H$. pylori with ulcer medication without ulcers. Hormozgan Med J 13: 81-87.

7. Cover TL, Blanke SR (2005) Helicobacter pylori VacA, a paradigm for toxin multifunctionality. Nat Rev Microbiol 3: 320-332.

8. Podzorski RP, Podzorski DS, Wuerth A, Tolia V (2003) Analysis of the vacA, cagA, cagE, iceA, and babA2 genes in Helicobacter pylori from sixty-one pediatric patients from the Midwestern United States. Diagn Microbiol Infect Dis 46: 8388.

9. Boquet P, Ricci V, Galmiche A, Gauthier NC (2003) Gastric cell apoptosis and $H$. pylori: has the main function of VacA finally been identified? Trends Microbiol 11: 410-413.

10. Shokohizadeh L, Mobarez M, Sadeghi-Zadeh M, Amini M (2006) Investigated the relationship between cag A gene in Helicobacter pylori and endoscopic findings. Kosar Med J 11: 266-271.

11. Latifi-Navid S, Siavoshi F, Fakheri H, Sharifian A, Nobakht H, Tavafzadeh R, Salman Roghani H, Behbahanian M, Massarrat S, Malekzadeh R (2011) Evolutionary dynamics of Helicobacter pylori cagA and vacA genes in Iran and their association with clinical outcomes. Govaresh J 15: 283-292.

12. Shokri Shirvani J, Rajabnia R, Tohidi F, Asmar M, Taheri H (2008) Outbreak of $\operatorname{cagA}$ and iceA in H. pylori strain isolated from patients with gastro duodenal diseases in Babol city. J Babol Univ Med Sci 10: 46-53.

13. Mollabashi Z, Zolfaghari M.R,Amini M, Salehi R (2012) The relation between microalbuminuria and Helicobacter pylori VacA gene in type 2 diabetic patients. J Isfahan Med Sch 30: 822-831.

14. Souod N, Kargar M, Doosti A, Ranjbar R, Sarshar M (2013) Genetic analysis of cagA and vacA genes in Helicobacter pylori isolates and their relationship with gastroduodenal diseases in the west of Iran. Iran Red Crescent Med J 15: 371 375. 
15. Bazargani A, Ekrami A, Bassiri E, Saber Firoozi M (2005) Frequency of cagA in Helicobacter pylori isolates of patients with peptic ulcer diseases (PUD) and nonulcer dyspepsia (NUD) at Namazi Hospital, Shiraz, Iran. Govaresh J 10: 116119.

16. Aqajani M, Abbasian M (2002) Chronic infection with Helicobacter pylori cagA+ strains and its association with coronary heart disease. Iran. South Med J 5: 62-56.

17. Shirazi MH, Ghasemi A, Khorammizadeh MR, Daryani NE, Hosseini M, Sadeghifard N (2006) Study of cagA gene in Helicobacter pylori strains isolated from patients with NUD, peptic ulcer and gastric cancer by PCR method. J Ilam Univ Med Sci 14: 22-28.

18. Ghasemian Safaei H, Tavakkoli H, Mojtahedi A,Salehei R, Soleimani B, Pishva E (2008) Correlation of cagA positive Helicobacter pylori infection with clinical outcomes in Alzahra hospital, Isfahan, Iran. J Research Med Sci 13: 196201.

19. Douraghi M, Mohammadi M, Shirazi MH, Oghalaie A, Saberi Kashani S, Mohagheghi MA, Eshagh Hosseini M, Zeraati H, Esmaili M, Bababeik M, Mohajerani N (2009) Simultaneous detection of cagA and cagE of Helicobacter pylori strains recovered from Iranian patients with different gastroduodenal diseases. Iran J Public Health 38: 98-105.

20. Molaei M, Foroughi F, Mashayekhi R, Jafari F, Dabiri H, Shokrzadeh L, Zojaji H, Hagh Azali M, Zali MR (2009) Helicobacter pylori cagA status, vacA subtypes and histopathologic findings in Iranian patients with chronic gastritis. Iran J Pathol 4: 19-25.

21. Ghasemi Kebria F, Bagheri H, Semnani S, Ghaemi E (2011) Seroprevalence of anti- HP and anti- $\mathrm{CagA}$ antibodies among healthy persons in Golestan province, northeast of Iran in 2010. Caspian J Intern Med 2: 256-260.

22. Bode G, Brenner H, Adler G, Rothenbacher D (2002) Dyspeptic symptoms in middle-aged to old adults: the role of Helicobacter pylori infection, and various demographic and lifestyle factors. J Intern Med 252: 41-47.

23. Ghotaslou R, Milani M, Akhi MT, Nahaei MR, Hasani A, Hejazi MS, Meshkini M (2013) Diversity of Helicobacter pylori cagA and vacA genes and its relationship with clinical outcomes in Azerbaijan, Iran. Adv Pharm Bull 3: 57-62.

24. Bojary MR, Foroozandeh M, Alvandi AH, Hashemi SM, Masjedian F, Nazifi A (2004) Study of the cagA gene prevalence in Helicobacter pylori strains isolated from patients with upper gastrointestinal disorders in Iran. Govaresh J 9: 176-180.

25. Nawfal RH, Mohammadi M, Talebkhan Y, Doraghi MP, Letley DK, Muhammad M, Argent HR, Atherton CJ (2008) Differences in virulence markers between Helicobacter pylori strains from Iraq and those from Iran: potential importance of regional differences in $H$. pylori-associated disease. J Clin Microbiol 46: 1774-1779.

26. Kamali-Sarvestani E, Bazargani A, Masoudian M, Lankarani K, Taghavi AR, Saberifiroozi M (2006) Association of $H$. pylori cagA and vacA genotypes and IL-8 gene polymorphisms with clinical outcome of infection in Iranian patients with gastrointestinal diseases. World J Gastroenterol 28: 5205-5210.

27. Jafari F, Shokrzadeh L, Dabiri H, Baghaei K, Yamaoka Y, Zojaji H, Haghazali M, Molaei M, Zali MR (2008) vacA genotypes of Helicobacter pylori in relation to cagA status and clinical outcomes in Iranian populations. Jpn J Infect Dis 61: 290-293.
28. Dabiri H, Maleknejad P, Yamaoka Y, Feizabadi MM, Jafari F, Rezadehbashi M, Nakhjavani FA, Mirsalehian A, Zali MR (2009) Distribution of Helicobacter pylori cagA, cagE, oipA and $v a c A$ in different major ethnic groups in Tehran, Iran. J Gastroenterol Hepatol 24: 1380-1386.

29. Saribasak H, Salih BA, Yamaoka Y, Sander E (2004) Analysis of Helicobacter pylori genotypes and correlation with clinical outcome in Turkey. J Clin Microbiol 42: 16481651.

30. Olivares A, Buadze M, Kutubidze T, Lobjanidze M, Labauri L, Kutubidze R, Chikviladze D, Zhvania M, Kharzeishvili O, Lomidze N, Perez-Perez GI (2006) Prevalence of Helicobacter pylori in Georgian patients with dyspepsia. Helicobacter 11: 81-85.

31. Ramelah M, Aminuddin A, Alfizah H, Isa MR, Jasmi AY, Tan HJ, Rahman AJ, Rizal AM, Mazlam MZ (2005) CagA gene variants in Malaysian Helicobacter pylori strains isolated from patients of different ethnic groups. FEMS Immunol Med Microbiol 44: 239-242.

32. Hatakeyama M, Higashi H (2005) Helicobacter pylori cagA: a new paradigm for bacterial carcinogenesis. Cancer Sci 96: 835-843.

33. Satomi S, Yamakawa A, Matsunaga S, Masaki R, Inagaki T, Okuda T, Suto H, Ito Y, Yamazaki Y, Kuriyama M, Keida Y, Kutsumi H, Azuma T (2006) Relationship between the diversity of the cagA gene of Helicobacter pylori and gastric cancer in Okinawa, Japan. J Gastroenterol 41: 668-673.

34. Reshetnikov OV, Kurilovich SA, Krotov SA, Krotova VA, Shumakov OV (2005) Relationship between CagA-bearing strains of Helicobacter pylori and gastrointestinal pathology. Ter Arkh 77: 25-28.

35. Sahara S, Sugimoto M, Vilaichone RK, Mahachai V, Miyajima H, Takahisa F, Yamaoka Y (2012) Role of Helicobacter pylori cagA EPIYA motif and vacA genotypes for the development of gastrointestinal diseases in Southeast Asian countries: a meta-analysis. BMC Infect Dis 12: 223237.

36. Nahaei M, Sharifi Y, Taghi Akhi M, Ashghaezade M, Nahayei M, Fatahi E (2008) Helicobacter pylori cagA and vacA genotypes and their relationship to peptic ulcer disease and non ulcer dysplasia. Rese J Microbiol 3(5): 386-94.

37. Zhou J, Zhang J, Xu C, He L (2004) CagA genotype and variants in Chinese Helicobacter pylori strains and relationship to gastroduodenal diseases. J Med Microbiol 53: 231-235.

38. Miehlike S, Schuppler M, Frings C, Kirsch C, Negraszus N, Morgner A, Stolte M, Ehninger G, Bayerdörffer E (2001) Helicobacter pylori vacA, iceA and cagA status and pattern of gastritis in patients with malignant and benign gastroduodenal disease. Am J Gastroentrol 96: 1008-1013.

39. Magalhaes AF, Carvalhaes A, Natan-Eisig J, Paraiso-Ferraz JG, Trevisan M, Zaterkaad S (2005) CagA status and Helicobacter pylori eradication among dyspeptic patients. Gastroenterol Hepatol 28: 441-444.

40. Peek RM Jr (2003) Intoxicated cells and stomach ulcers. Nat Genet 33: 328-330.

41. Bolek BK, Salih BA, Sander E (2007) Genotyping of Helicobacter pylori strains from gastric biopsies by multiplex polymerase chain reaction. How advantageous is it? Diagn Microbiol Infect Dis 58: 67-70.

42. Tan HJ, Rizal AM, Rosmadi MY, Goh KL (2005) Distribution of Helicobacter pylori cagA, cagE and vacA in 
different ethnic groups in Kuala Lumpur, Malaysia. J Gastroenterol Hepatol 20: 589-594.

43. Chomvarin C, Namwat W, Chaicumpar K, Mairiang $P$, Sangchan A, Sripa B, Tor-Udom S, Vilaichone RK (2008) Prevalence of Helicobacter pylori vacA, cagA, cagE, iceA and babA2 genotypes in Thai dyspeptic patients. Int $\mathbf{J}$ Infect Dis 12: 30-36.

44. Kim SY, Woo CW, Lee YM, Son BR, Kim JW, Chae HB, Youn SJ, Park SM (2001) Genotyping CagA, VacA subtype, IceA1, and BabA of Helicobacter pylori isolates from Korean patients, and their association with gastroduodenal diseases. $\mathbf{J}$ Korean Med Sci 16: 579-584.

45. Maeda S, Yoshida H, Ikenoue T, Ogura K, Kanai F, Kato N, Shiratori Y, Omata M (1999) Structure of cag pathogenicity island in Japanese Helicobacter pylori isolates. Gut 44: 336341.

46. Miehlke S, Kirsch C, Agha-Amiri K, Gunther T, Lehn N, Malfertheiner P, Stolte M, Ehninger G, Bayerdorffer E (2000) The Helicobacter pylori vacA $\mathrm{s} 1, \mathrm{~m} 1$ genotype and cagA is associated with gastric carcinoma in Germany. Int $\mathrm{J}$ Cancer 87: $322-327$

47. Rezaeian AA, Kargar M, Souod N, Ghorbani Dalini S (2012) Genetic polymorphisms of cagA and vacA genes in Helicobacter pylori isolates from Chaharmahal and Bakhtiari Province, Iran. J Isfahan Med Sch 30: 1019-1027.

48. Beil W, Enss ML, Muller S, Obst B, Sewing KF, Wagner S (2000) Role of vacA and cagA in Helicobacter pylori inhibition of mucin synthesis in gastric mucous cells. J Clin Microbiol 38: 2215-2218.

49. Sayehmiri F, Darvishi Z, Sayehmiri K, Soroush S, Emaneini M, Zarrilli R, Taherikalani M (2014) A systematic review and meta-analysis study to investigate the prevalence of Helicobacter pylori and the sensitivity of its diagnostic methods in Iran. Iran Red Crescent Med J 16: 1-8.

50. Latifi-Navid S, Ghorashi SA, Siavoshi F, Linz B, Massarrat S, Khegay T, Salmanian AH, Shayesteh AA, Masoodi M, Ghanadi K, Ganji A, Suerbaum S, Achtman M, Malekzadeh R, Falush D (2010) Ethnic and geographic differentiation of Helicobacter pylori within Iran. PloS One 5: e9645.

51. Huang JQ, Zheng GF, Sumanac K, Irvine EJ, Hunt RH (2003) Meta-analysis of the relationship between $\mathrm{cagA}$ seropositivity and gastric cancer. Gastroenterology 125: 1636-1644.

52. Romano M, Ricci V, Zarrilli R (2006) Mechanisms of disease: Helicobacter pylori related gastric carcinogenesisimplications for chemoprevention. Nat Clin Pract Gastroenterol Hepatol 3: 622-632.

53. Matos JI, de Sousa HA, Marcos-Pinto R, Dinis-Ribeiro M (2013) Helicobacter pylori cagA and vacA genotypes and gastric phenotype: a meta-analysis. Eur J Gastroenterol Hepatol 25: 1431-1441.

54. Jafarzadeh A, Rezayati MT, Nemati M (2007) Specific serum immunoglobulin $\mathrm{G}$ to $H$. pylori and $\operatorname{cag} A$ in healthy children and adults (south-east of Iran). World J Gastroenterol 13: 3117-3121.

55. Suzuki T, Matsuo K, Sawaki A, Hirose K, Wakai K, Sato S, Nakamura T, Yamao K, Ueda R, Tajima K (2006) Systematic review and meta-analysis: importance of cagA status for successful eradication of Helicobacter pylori infection. Aliment Pharmacol 24: 273-280.

56. Tan HJ, Rizal AM, Rosmadi MY, Goh KL (2006) Role of Helicobacter pylori virulence factor and genotypes in nonulcer dyspepsia. J Gastroenterol Hepatol 21: 110-115.
57. Chen XJ, Yan J, Shen YF (2005) Dominant CagA/VacA genotypes coinfection frequency of Helicobacter pylori in peptic ulcer or chronic gastritis patients in Zhejiang Province and correlations among different genotypes, coinfection and severity of the diseases. Chin Med J 118: 460-467.

58. Bulent K, Murat A, Esin A, Fatih K, Murat H, Hakan H, Melih K, Mehmet A, Bulent Y, Fatih H (2003) Association of cagA and vacA presence with ulcer and non-ulcer dyspepsia in a Turkish population. World J Gastroenterol 9: 1580-1583.

59. Audibert C, Janvier B, Grignon B, Salaun L, Burucoa C, Lecron JC, Fauchère JL (2000) Correlation between IL-8 induction, cagA status and vacA genotypes in 153 French Helicobacter pylori isolates. Res Microbiol 151: 191-200.

60. Weel JF, van der Hulst RW, Gerrits Y, Roorda P, Feller M, Dankert J, Tytgat GN, van der Ende A (1996) The interrelationship between cytotoxin-associated gene A, vacuolating cytotoxin, and Helicobacter pylori-related diseases. J Infect Dis 173: 1171-1175.

61. Ito A, Fujioka T, Kodama K, Nishizono A, Nasu M (1997) Virulence-associated genes as markers of strain diversity in Helicobacter pylori infection. J Gastroenterol Hepatol 12: 666-669.

62. Sugimoto M, Yamaoka Y (2009) The association of vacA genotype and Helicobacter pylori-related disease in Latin American and African populations. Clin Microbiol Infect 15: 835-842.

63. Wong BC, Yin Y, Berg DE, Xia HH, Zhang JZ, Wang WH, Wong WM, Huang XR, Tang VS, Lam SK (2001) Distribution of distinct vacA, cagA and iceA alleles in Helicobacter pylori in Hong Kong. Helicobacter 6: 317-324.

64. Guillemin K, Salama NR, Tompkins LS, Falkow S (2002) Cag pathogenicity Island-specific responses of gastric epithelial cells to Helicobacter pylori infection. Proc Natl Acad Sci U S A 99: 15136-15141.

65. Zhang W (2001) Helicobacter pylori prevalence and cagA status among children in two countries. Ann Epidemol 11: 543-546.

66. Aydin F, Kaklikkaya N, Ozgur O, Cubukcu K, Kilic AO, Tosun I, Erturk M (2004) Distribution of vacA alleles and cagA status of Helicobacter pylori in peptic ulcer disease and non- ulcer dyspepsia. Clin Microbiol Infect 10: 1102-1104.

67. Figueiredo C, Van Doorn LJ, Nogueira C, Soares JM, Pinho C, Figueira P, Quint WG, Carneiro F (2001) Helicobacter pylori genotypes are associated with clinical outcome in Portuguese patients and show a high prevalence of infections with multiple strains. Scand J Gastroenterol 36: 128-135.

68. Arents NL, Van Zwet AA, Thijs JC, Kooistra-Smid AM, van Slochteren KR, Degener JE, Kleibeuker JH, van Doorn LJ (2001) The importance of vacA, cagA and iceA genotypes of $H$. pylori infection in peptic ulcer disease and gastroesophageal reflux disease. Am J Gastroenterol 96: 2603-2608.

69. Rhead JL, Letley DP, Mohammadi M, Hussein N, Mohagheghi MA, Eshagh Hosseini M, Atherton JC (2007) A new Helicobacter pylori vacuolating cytotoxin determinant, the intermediate region, is associated with gastric cancer. Gastroenterology 133: 926-936.

70. Orsini B, Ciancio G, Surrenti E, Macrí G, Biagini MR, Milani S, Surrenti C (1998) Serologic detection of cagA positive Helicobacter pylori infection in a northern Italian population. Helicobacter 3: 15-20. 
71. Gzyl A, Berg DE, Dzierzanowska D (1997) Epidemiology of cagA/vacA genes in $H$. pylori isolated from children and adults in Poland. J Physiol Pharmacol 48: 333-343.

72. Li J, Ou Z, Wang F, Guo Y, Zhang R, Zhang J Li P, Xu W, He Y (2009) Distinctiveness of the cagA genotype in children and adults with peptic symptoms in South China. Helicobacter 14: 248-255.

73. Covacci A, Telford JL, Del Guidance G, Parsonnet J, Rappuoli R (1999) H. pylori virulence and genetic geography. Science 284: 1328-1333.

74. Saribas KH, Salih BA, Yamaoka Y, Sander E (2004) Analysis of $H$. pylori genotypes and correlation with clinical outcome in Turkey. J Clin Microbiol 42: 1648-1651.

75. Kuo CH, Wu DC, Lu CY, Su YC, Yu FJ, Lee YC, Wu IC, Lin SR, Liu CS, Jan CM, Wang WM (2003) Low molecular weight protein of Helicobacter pylori and its relation to gastroduodenal diseases. Hepatogastroenteroly 50: 897-901.

76. Qiao W, Hu JL, Xiao B, Wu KC, Peng DR, Atherton JC, Xue $\mathrm{H}$ (2003) cagA and vacA genotype of Helicobacter pylori associated with gastric diseases in Xi'an area. World $\mathbf{J}$ Gastroenterol 9: 1762-1766.

77. Shiota S, Matsunari O, Watada M, Yamaoka Y (2010) Serum Helicobacter pylori cagA antibody as a biomarker for gastric cancer in East Asian countries. Future Microbiol 5: 18851893.

78. Salama NR, Hartung ML, Müller A (2013) Life in the human stomach: persistence strategies of the bacterial pathogen Helicobacter pylori. Nat Rev Microbiol 11: 385-399.
79. Rad R, Neu B (2004) Cytokine gene polymorphism influence mucosal cytokine expression, gastric inflammation, and host specific colonization during Helicobacter pylori infection. Gut 53: 1082-1089.

80. Sugimoto M, Zali MR, Yamaoka Y (2009) The association of vacA genotypes and Helicobacter pylori-related gastroduodenal diseases in the Middle East. Eur J Clin Microbiol Infect Dis 28: 1227-1236.

81. Lissowska J, Yuan CC, Rothman N, Lanyon G, Martin M, Fraumeni JF Jr, Rabkin CS (2000) Interleukin-1 polymorphisms associated with increased risk of gastric cancer. Nature 23: 398-402.

82. Lu W, Pan K, Zhang L, Lin D, Miao X, You W (2005) Genetic polymorphisms of interleukin (IL)-1B, IL-1RN, IL-8, IL-10 and tumor necrosis factor \{alpha\} and risk of gastric cancer in a Chinese population. Carcinogenesis 26: 631-636.

\section{Corresponding author}

Morovat Taherikalani

Department of Microbiology

School of Medicine

Lorestan University of Medical Sciences, Khorramabad, Iran

Phone: +98 663- 3227593

Fax: +98 663- 3227593

Email: taherikalani@gmail.com

Conflict of interests: No conflict of interests is declared. 